\title{
Spatial and seasonal patterns in fish assemblage in Córrego Rico, upper Paraná River basin
}

\author{
Erico L. H Takahashi ${ }^{1}$, Fabricio R. T. Rosa ${ }^{2}$, Francisco Langeani ${ }^{2,3}$ \\ and Laura S. O. Nakaghi' ${ }^{2,4}$
}

\begin{abstract}
The upper Paraná River basin drains areas of intensive industry and agriculture, suffering negative impacts. The Córrego Rico flows through sugar cane fields and receives urban wastewater. The aim of this work is to describe and to compare the fish assemblage structure in Córrego Rico. Six standardized bimonthly samples were collected between August 2008 and June 2009 in seven different stretches of Córrego Rico. Fishes were collected with an experimental seine and sieves, euthanized, fixed in formalin and preserved in ethanol for counting and identification. Data were recorded for water parameters, instream habitat and riparian features within each stretch. Non-metric multidimensional scaling, species richness and diversity analysis were performed to examine spatial and seasonal variation in assemblage structure. Fish assemblage structure was correlated with instream habitat and water parameters. The fish assemblage was divided in three groups: upper, middle and lower reaches. High values of richness and diversity were observed in the upper and lower stretches due to connectivity with a small lake and Mogi Guaçu River, respectively. Middle stretches showed low values of richness and diversity suggesting that a small dam in the middle stretch negatively impacts the fish assemblage. Seasonal differences in fish assemblage structure were observed only in the lower stretches.
\end{abstract}

A bacia do alto rio Paraná drena áreas caracterizadas pela agricultura e industrialização intensiva, sofrendo vários impactos negativos. O Córrego Rico é um tributário da bacia do alto rio Paraná que atravessa áreas de cultivo de cana-de-açúcar e recebe esgoto doméstico. O objetivo do presente trabalho é descrever e comparar a estrutura da assembleia de peixes no Córrego Rico. Foram realizadas amostragens padronizadas bimestrais, entre agosto de 2008 e junho de 2009, em sete trechos do rio com diferentes condições ambientais. Foram utilizadas redes de arrasto e peneiras. Os peixes coletados foram fixados, identificados, listados e quantificados. Caracterização ambiental e da qualidade da água foram realizadas nos trechos amostrados. Foram utilizados análise multivariada, estimadores de riqueza e diversidade para analisar os dados. A estrutura da assembleia de peixes foi relacionada com estrutura do leito do rio e pelas características físicas e químicas da água. A assembleia de peixes foi dividida em três grupos: trecho superior, médio e inferior. Altos valores de riqueza e diversidade foram observados nos trechos superior e inferior devido a conectividade com um pequeno lago e o rio Mogi Guaçu, respectivamente. Baixos valores de riqueza e diversidade foram observados nos trechos médios, sugerindo que uma barragem entre estes trechos causa impacto na assembleia de peixes do Córrego Rico. Diferenças sazonais na estrutura da assembleia de peixes foram observadas somente no trecho inferior.

Key words: Dam effects, Diversity, Ecology, Mogi Guaçu River.

\section{Introduction}

Fish assemblage structure in rivers has been shown to be influenced by biogeography and historical factors (Ribeiro, 2006), variability in hydrology (Poff \& Allan, 1995; Taylor et al., 2006; Valerio et al., 2007), physicochemical and environmental factors (Angermeier \& Schlosser, 1989; Penczak et al., 1994; Winemiller et al., 2000; Abes \& Agostinho, 2001; Walters et al., 2003; Casatti et al., 2006b), and biotic interactions such as predation and competition (Taylor, 1997; Taylor \& Warren, 2001). Another important factor determining fish distributions is human impact. Rivers

\footnotetext{
${ }^{1}$ Universidade Federal do Amazonas, Instituto de Ciências Exatas e Tecnologia. Avenida Nossa Senhora do Rosário, 3863, 69103-128 Itacoatiara, Amazonas, Brazil. ericolht@yahoo.com.br

${ }^{2}$ Universidade Estadual Paulista "Júlio de Mesquita Filho", Centro de Aquicultura da UNESP (CAUNESP). Via Prof. Paulo Donato Castellane s/n, 14884-900 Jaboticabal, São Paulo, Brazil.

${ }^{3}$ Universidade Estadual Paulista "Júlio de Mesquita Filho", Instituto de Biociências, Letras e Ciências Exatas, Departamento de Zoologia e Botânica, Laboratório de Ictiologia. Rua Cristovão Colombo 2265, 15054-000 São José do Rio Preto, São Paulo, Brazil.

${ }^{4}$ Universidade Estadual Paulista "Júlio de Mesquita Filho", Faculdade de Ciências Agrárias e Veterinárias, Departamento de Morfologia e Fisiologia Animal. Via Prof. Paulo Donato Castellane s/n, 14884-900 Jaboticabal, São Paulo, Brazil.
} 
throughout the world have experienced massive changes ranging from reduced fish population abundance and aquatic biodiversity to habitat fragmentation and exotic species invasion (Pringle et al., 2000).

In Brazil, the regulation of flow by dams has modified the structure and function of the upper Paraná River and negatively impacted the fish fauna (Agostinho et al., 2003). The upper Paraná River basin covers 32\% of Brazil's territory, and contains most of the country's industry and vast regions of intense agriculture (Agostinho et al., 2007). The Córrego Rico is a stream within the upper Paraná River that flows through areas dominated by sugar cane culture. The stream supplies water and receives waste from several cities. This study addresses two main questions: 1- Are there spatial and seasonal differences in fish species composition in Córrego Rico stream? 2-What are the relationships between fish assemblage structure and environmental variables?

\section{Material and Methods}

Study area. Córrego Rico is a sixth-order stream located at northern São Paulo State, Brazil (Fig. 1). The stream flows through five municipalities over a distance of approximately $60 \mathrm{~km}$ until discharging into the Mogi Guaçu River. In the upper portion, the stream receives treated sewage from Monte Alto city (population $c a .45,000$ ). In the middle and lower course, the stream supply water for the city of Jaboticabal

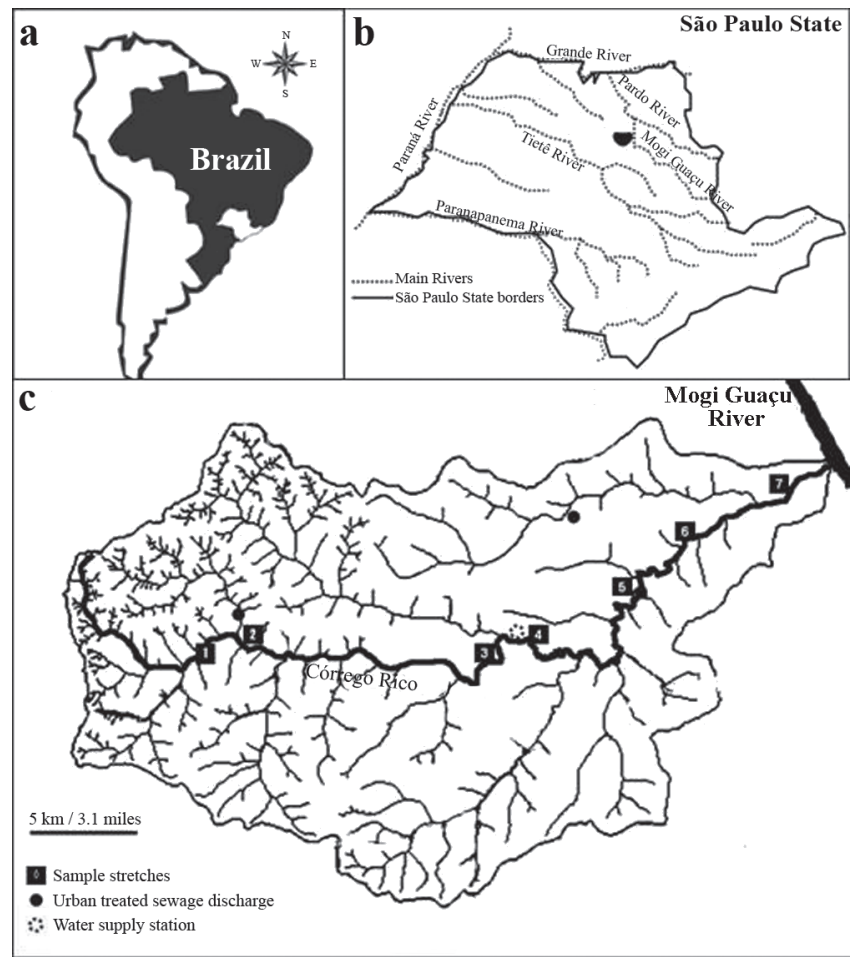

Fig. 1. a) Map of South America with Brazil location. b) Córrego Rico basin in São Paulo State. c) Córrego Rico basin (Modified from a figure by L. A. Amaral - unpublished) with the samples stretches. (population $c a .70,000$ ) and receives its treated sewage effluent. The region climate is hot and humid during summer and cool during winter. The average temperature of the hottest month (February) is $25.4^{\circ} \mathrm{C}$ and for the coldest month (July) is $20.1^{\circ} \mathrm{C}$. Mean annual precipitation in region varies from 11 to $17 \mathrm{~cm}$, with the rains concentrated between October and March. The dry season is from April to September. The original vegetation was tropical evergreen forest, but currently sugar cane is the predominant vegetation (Borges et al., 2003).

Sampling protocol. Six bimonthly standardized samples were collected between August 2008 and June 2009 in seven different stretches of Córrego Rico (Fig. 1; Table 1). These stretches were chosen according to their accessibility by road, position along the river (upper, middle, and lower stretches) and possible anthropogenic influence. About 100 meters upstream from first sample stretch, S1, Córrego Rico flows through a low area characterized as a small lake, with emerged and submerged macrophytes, low depth (less than 2.0 meters), high water transparency, large amount of unconsolidated substrate, and very low flow velocity (E. L. H. T., pers. obs.). Stretch S1 $\left(21^{\circ} 18^{\prime} 37.4^{\prime \prime} \mathrm{S} 48^{\circ} 27^{\prime} 39.1^{\prime \prime} \mathrm{W}\right)$ is a fourth-order stretch upstream from the discharge of treated sewage from Monte Alto municipality. Stretch S2 $\left(21^{\circ} 18^{\prime} 43.8^{\prime \prime} \mathrm{S}\right.$ $48^{\circ} 26^{\prime} 54.1^{\prime \prime} \mathrm{W}$ ) is a fifth-order segment downstream of the discharge of treated sewage from Monte Alto city. Stretch S3 $\left(21^{\circ} 18^{\prime} 45,8^{\prime} \mathrm{S} 48^{\circ} 19^{\prime} 30.6^{\prime \prime} \mathrm{W}\right)$ is a fifth-order stretch located upstream the Jabotical municipality water supply dam station, and stretch S4 (21 $\left.{ }^{\circ} 18^{\prime} 36.4^{\prime \prime} \mathrm{S} 48^{\circ} 19^{\prime} 19.7^{\prime \prime} \mathrm{W}\right)$ is a sixth-order stretch located $0.7 \mathrm{~km}$ downstream from S3. Stretch S5 $\left(21^{\circ} 17^{\prime} 56.4^{\prime \prime} \mathrm{S} 48^{\circ} 15^{\prime} 58.0^{\prime \prime} \mathrm{W}\right)$ is upstream from a small village. Stretch S6 (21 $\left.{ }^{\circ} 15^{\prime} 56.1^{\prime \prime} \mathrm{S} 48^{\circ} 14^{\prime} 12.2^{\prime \prime} \mathrm{W}\right)$ is upstream from the confluence with a stream that receives treated sewage from

Table 1. Stretch order (Horton, 1945; Strahler, 1957), distance from spring and visual habitat estimation (USEPA, 1997) for the sampling stretches in Córrego Rico.

\begin{tabular}{|c|c|c|c|c|c|c|c|c|}
\hline \multicolumn{2}{|l|}{ Stretches } & S1 & S2 & S3 & S4 & S5 & S6 & S7 \\
\hline \multicolumn{2}{|l|}{$\overline{\text { Order }}$} & $4^{\circ}$ & $5^{\circ}$ & $5^{\circ}$ & $6^{\circ}$ & $6^{\circ}$ & $6^{\circ}$ & $6^{\circ}$ \\
\hline \multicolumn{2}{|l|}{$\begin{array}{l}\text { Distance from } \\
\text { the spring }(\mathrm{km})\end{array}$} & 11.1 & 12.5 & 29.3 & 30.0 & 41.0 & 50.0 & 57.0 \\
\hline \multicolumn{2}{|l|}{$\begin{array}{l}\text { Stream } \\
\text { shading (\%) }\end{array}$} & 20 & 70 & 90 & 40 & 30 & 10 & 30 \\
\hline \multirow{3}{*}{ Habitats (\%) } & Pool & 20 & 20 & 30 & 10 & 30 & 10 & 10 \\
\hline & Riffle & 30 & 20 & 50 & 60 & 00 & 40 & 40 \\
\hline & Run & 50 & 60 & 20 & 30 & 70 & 50 & 50 \\
\hline \multirow{6}{*}{ Substrate $(\%)$} & Silt & 50 & 50 & 20 & 10 & 70 & 70 & 20 \\
\hline & Sand & 35 & 20 & 10 & 10 & 30 & 20 & 15 \\
\hline & Gravel & 10 & 20 & 05 & 20 & - & 10 & 05 \\
\hline & Cobbles & 05 & 10 & 10 & 05 & - & - & 05 \\
\hline & Boulders & - & - & 30 & 05 & - & - & 05 \\
\hline & Bedrock & - & - & 20 & 50 & - & - & 50 \\
\hline \multirow{5}{*}{$\begin{array}{l}\text { Stream side } \\
\text { cover }(\%)\end{array}$} & Tress & 10 & 60 & 70 & 30 & 20 & 10 & 20 \\
\hline & Bushes & 25 & 20 & 20 & 20 & 30 & 10 & 30 \\
\hline & Tall grass & 60 & 15 & 10 & 50 & 50 & 30 & 50 \\
\hline & Bare soil & - & - & - & - & - & 35 & - \\
\hline & $\begin{array}{l}\text { Pavement } \\
\text { structure }\end{array}$ & 05 & 05 & - & - & - & 05 & - \\
\hline
\end{tabular}


Jaboticabal municipality. Stretch S7 $\left(21^{\circ} 13^{\prime} 59.5^{\prime \prime S}\right.$ $48^{\circ} 10^{\prime} 45.4^{\prime \prime} \mathrm{W}$ ) is located above the confluence with the stream that receives treated sewage from Jaboticabal municipality, and about $2.0 \mathrm{~km}$ upstream from the confluence with the Mogi Guaçu River. Stretch S1 is $584 \mathrm{~m}$ above sea level, and S7 is 503 $\mathrm{m}$ above sea level.

Fishes were sampled with a rectangular seine net (with 2.5 x 1.0 meters, $2 \mathrm{~mm}$ mesh) and two rectangular sieves nets (with $0.7 \times 0.4$ meters and deep 0.3 meters, $2 \mathrm{~mm}$ mesh). The sampling effort was 40 minutes in a segment of 100 meters within each stretch. In the field, fishes were euthanized on ice and immediately fixed in formalin $10 \%$. After 72 hours, fish were washed in water and preserved in $70 \%$ ethanol for counting and identification. Voucher specimens are deposited in Coleção de Peixes do Departamento de Zoologia (DZSJRP) IBILCE/ UNESP, São José do Rio Preto, SP.

Visual percentage estimation of canopy covers shading, type and quantity of habitat (riffle, run, pool), substrate (silt, sand, gravel, cobbles, boulders, and bedrock) stream side cover (trees, bushes, tall grass, bare soil, and pavement structure) were performed according USEPA (1997) in each stretch (Table 2). To estimate stream discharge at each survey site, channel width and depth were measured and water velocity was estimated using the float method in three transects (USEPA, 1997). Electronic sensors measured dissolved oxygen (Yellow Spring Instruments 550A), temperature, conductivity and $\mathrm{pH}$ (Yellow Spring Instruments 63). In the laboratory total phosphorus, ammonia, nitrite and nitrate concentrations were measured according to methods described in Eaton et al. (1998).

Data analysis. The fish abundance matrix was analyzed with non-metric multidimensional scaling (NMDS) with the software PC-ORD 5.21 (McCune \& Mefford, 2006). To perform the analysis the dataset was divided into dry (June, August, and October) and rainy (December, February, and April) seasons according rainfall and average temperature data (CIIAGRO). In the rainy season, monthly accumulated rainfalls were between 70.8 and $278.0 \mathrm{~cm}$, and average monthly temperatures were between 23.6 and $25.2^{\circ} \mathrm{C}$. In the dry season, monthly accumulated rainfall values were between 24.2 and $51.9 \mathrm{~cm}$, and average monthly temperatures were between 20.1 and $25.0^{\circ} \mathrm{C}$. Abundance data were transformed $\left[\log _{10}(\mathrm{X}+1)\right]$, Bray-Curtis dissimilarity was used as measure of distance, and species with less than 10 individuals collected were excluded from the analysis. The rarefaction method and Shannon's index (Magurran, 1988) were used to estimate species richness and diversity, respectively, in each stretch. Differences among stretch's diversity were compared with Student's $t$-test. The analysis were performed in the Past software (Hammer et al., 2001).

The environmental variables matrix also was analyzed with NMDS (Sousa et al., 2008). Euclidian distance was used as measure of distance. A second analysis was performed with the dataset divided into dry (June, August, and October) and rainy (December, February, and April) seasons. An analysis of variance (ANOVA) was performed with the variables with highest correlation with the axis of NMDS. The a posteriori
Tukey test was performed to compare mean values of variables between stretches.

Axes from NMDS analysis of fish abundances were correlated (Pearson correlation) with environmental data to identify variables most strongly corresponding to amongstretches differences in fish assemblages.

\section{Results}

In the multivariate analysis for physical and chemical features, the first axis explained $94.0 \%$ of variance and the second $5.90 \%$ (total $=100 \%$ ), with stress of 0.397 (Fig. 2a). The NMDS grouped samples from stretches S3, S4, S5 and S6. S1 samples plotted together in a different region of the two-dimensional space. Samples from stretch S2 tended to plot near those from S7. Except for S2, the NMDS graphs did not show seasonal differences between stream stretches. Variables with highest correlation with the first axis were ammonia concentration $\left(\mathrm{r}=-0.99, \mathrm{r}^{2}=98.8 \%\right)$, total phosphorus concentration $\left(\mathrm{r}=-0.86, \mathrm{r}^{2}=74.6 \%\right)$ and nitrite concentration $\left(\mathrm{r}=-0.79, \mathrm{r}^{2}=63.1 \%\right)$. The variables with highest correlations with the second axis were nitrate $\left(\mathrm{r}=0.83, \mathrm{r}^{2}=70.24 \%\right)$, width $\left(\mathrm{r}=61.9, \mathrm{r}^{2}=38.0 \%\right)$ and dissolved oxygen $\left(\mathrm{r}=-0.59 \mathrm{r}^{2}=34.8 \%\right)$.

When the samples were grouped and environmental values averaged according to dry and rainy seasons, the first NMDS axis explained $92.0 \%$ of variance and the second axis explained $8.0 \%$ (total $=100 \%$ ), with stress of 0.003 (Fig. 2b). In both cases (Fig. 2a and 2b) the general pattern was similar. The variables with highest correlation with the first axis were ammonia concentration $\left(\mathrm{r}=-0.97, \mathrm{r}^{2}=94.2 \%\right)$, total phosphorus $\left(\mathrm{r}=-0.88, \mathrm{r}^{2}=77.8 \%\right)$ and specific conductivity $(\mathrm{r}=-0.81$, $\mathrm{r}^{2}=72.5 \%$ ), whereas in the second axis were ammonia concentration $\left(\mathrm{r}=-0.82, \mathrm{r}^{2}=74.3 \%\right)$, nitrite $\left(\mathrm{r}=-0.85, \mathrm{r}^{2}=63.1 \%\right)$ and total phosphorus concentration $\left(\mathrm{r}=-0.79, \mathrm{r}^{2}=62.7 \%\right)$.

The ANOVA for the variables having highest correlations with NMDS axes 1 and 2 showed that stretches S2 and S7 had significantly different values for nitrite and ammonia concentration compared to all other stretches (Table 2). Conductivity and total phosphorus were greatest in stretch S2, which differed significantly from the others stretches. Dissolved oxygen was the same in stretches S1 and S2, and these stretches were significantly different from stretches S3, S4, S5 and S6. Stretch S7 was significantly different only from $\mathrm{S} 1$.

A total of 6,094 fishes representing 58 species were collected (Table 3). Thirty-three species were Characiformes (56.9\%), 18 Siluriformes (31.0\%), three Perciformes (Cichlidae), two Gymnotiformes, one Synbranchiformes, and one Cyprinodontiformes. The most abundant species were small tetras, such as Piabina argentea $(\mathrm{N}=1512,19.79 \%)$, Bryconamericus stramineus ( $\mathrm{N}=937,15.37 \%)$, Astyanax fasciatus $(\mathrm{N}=605,9.93 \%)$ and 'Cheirodon' stenodon $(\mathrm{N}=412$, $6.76 \%)$. Piabina argentea was most abundant in stretches S1, S5 and S6, Bryconamericus stramineus in stretches S3 and $\mathrm{S} 4$, Poecilia reticulata in stretch $\mathrm{S} 2$ and the mailed catfish Hypostomus nigromaculatus in stretch S7 (Table 3). 

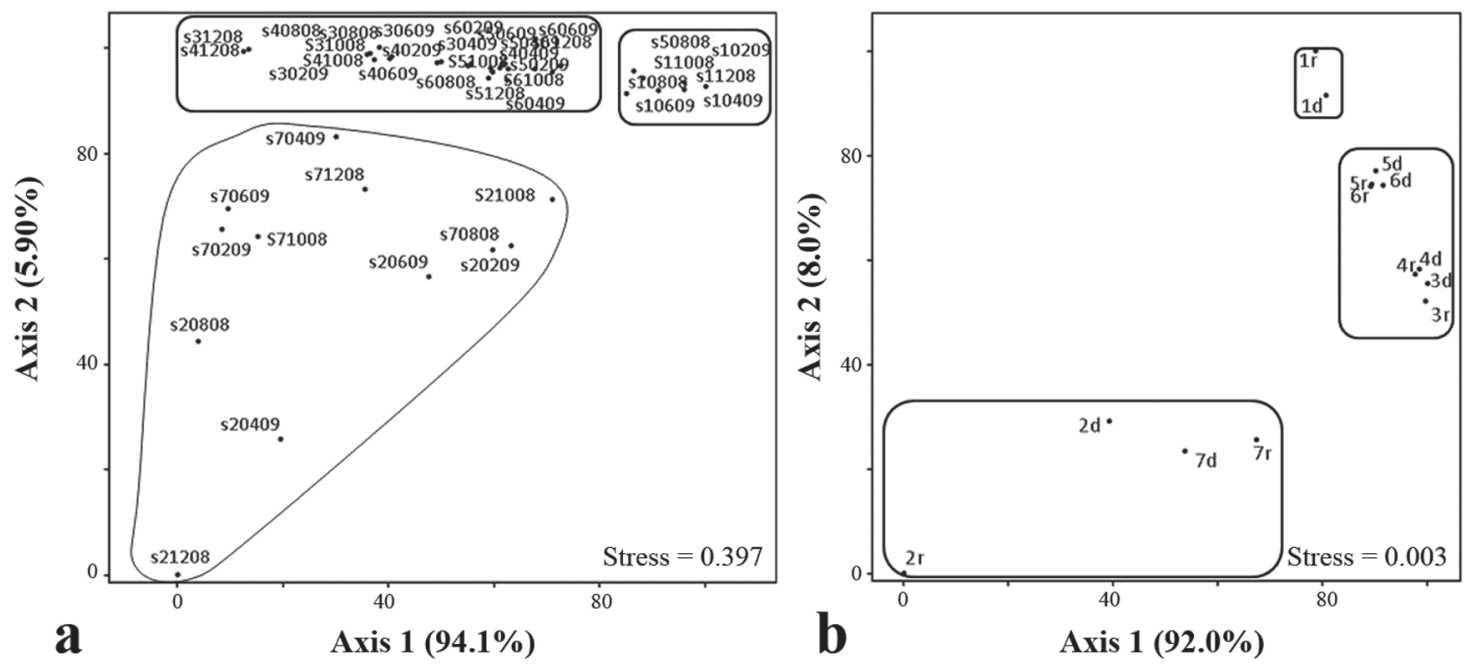

Fig. 2. Non-metric multidimensional scaling (NMDS) ordination of environmental variables data from Córrego Rico stretches. a) All samples (stretches - S1 to S7; month and year of sample - mmyy): b) Samples divided in rainy (R) and dry (D) seasons (stretches - S1 to S7).

The multivariate analysis based on fish abundance data revealed several pronounced patterns. The first NMDS axis explained $44.8 \%$ of variance and the second $46.9 \%$ (total $=91.7$ $\%$ ), with stress of 8.66 (Fig. 3). The NMDS analysis grouped the two upper stretches (S1, S2), and within this group dry and rainy seasons of S1 and S2 positioned close together. In the group formed by middle stretches (S3, S4 and S5) rainy and dry seasons were not cluster together in relation to each stretch. The lower stretches (S6, S7) were not grouped with the other stretches. During the dry season, S6 was similar to stretches S3, S4 and S5, but in the rainy season $\mathrm{S} 6$ was not similar to any other samples.

Upper and lower stretches showed different diversity from middle stretches, mainly during rainy season, and were plotted in the bottom part of the NMDS graph. The upper stretch, S1, showed similar diversity between the seasons and with $\mathrm{S} 2$ in rainy season. In dry season, S2 was similar with middle stretches S4 and S5 (Table 4). During the rainy season, the lower stretches, S6 and S7, showed different diversity between them and from all others stretches, in rainy and dry season. But in dry season, S6 and S7 were similar between them and with the upper stretches, S1 and S2 in dry and rainy season. The highest values for richness were in the lower stretches (S6, S7). The middle stretches, S3 and S4, in rainy season, showed lower diversity than dry season. And S3, S4, and S5, in rainy season, showed the lowest diversity. The lowest richness was observed in stretches S3 and S4 (Table 4).

The fish species with highest correlations with the first axis were Serrapinnus heterodon $\left(\mathrm{r}=-0.73, \mathrm{r}^{2}=53.7 \%\right)$, present only in stretches S4, S6 and S7, P. argentea $\left(\mathrm{r}=0.70, \mathrm{r}^{2}=49.3 \%\right)$ and Geophagus brasiliensis $\left(\mathrm{r}=0.68, \mathrm{r}^{2}=46.4 \%\right)$. Piabina and Geophagus were particularly abundant in stretch S1. The fish species with highest correlations with the second axis were 'Cheirodon' stenodon $\left(\mathrm{r}=-0.89, \mathrm{r}^{2}=80.6 \%\right)$, which was abundant in stretch S1, Paravandellia oxyptera $\left(\mathrm{r}=0.75, \mathrm{r}^{2}=57.5 \%\right)$,

Table 2. Mean, standard deviation, $F$ and $p$ values of analysis of variance (ANOVA) from environmental variables highest correlated with NMDS ordination among seven stretches of Córrego Rico (S1 to S7). Different superscript letters indicate significant difference among stretches.

\begin{tabular}{|c|c|c|c|c|c|c|c|c|c|}
\hline Variables & S1 & S2 & S3 & S4 & S5 & S6 & S7 & $\mathrm{F}$ & $p$ \\
\hline $\begin{array}{l}\text { Nitrite } \\
(\mu \mathrm{g} / \mathrm{L})\end{array}$ & $\begin{array}{l}2,39^{\mathrm{a}} \\
\pm 1,98\end{array}$ & $\begin{array}{l}33,40^{\mathrm{b}} \\
\pm 23,77\end{array}$ & $\begin{array}{l}6,81^{\mathrm{a}} \\
\pm 5,74\end{array}$ & $\begin{array}{l}5,21^{\mathrm{a}} \\
\pm 4,06\end{array}$ & $\begin{array}{l}3,32^{\mathrm{a}} \\
\pm 2,80\end{array}$ & $\begin{array}{l}5,24^{\mathrm{a}} \\
\pm 1,24\end{array}$ & $\begin{array}{l}46,58^{b} \\
\pm 22,16\end{array}$ & 11,81 & $<0,001$ \\
\hline $\begin{array}{c}\text { Ammonia } \\
(\mu \mathrm{g} / \mathrm{L})\end{array}$ & $\begin{array}{r}31,48^{\mathrm{a}} \\
\pm 22,70 \\
\end{array}$ & $\begin{array}{l}908,13^{\mathrm{b}} \\
\pm 462,39 \\
\end{array}$ & $\begin{array}{r}27,95^{\mathrm{a}} \\
\pm 18,00 \\
\end{array}$ & $\begin{array}{l}30,77^{\mathrm{a}} \\
\pm 7,71\end{array}$ & $\begin{array}{r}26,28^{\mathrm{a}} \\
\pm 21,97 \\
\end{array}$ & $\begin{array}{r}33,06^{\mathrm{a}} \\
\pm 19,07 \\
\end{array}$ & $\begin{array}{l}507,45^{\mathrm{c}} \\
\pm 125,88 \\
\end{array}$ & 22,29 & $<0,001$ \\
\hline $\begin{array}{c}\text { Total phosphorus } \\
(\mu \mathrm{g} / \mathrm{L})\end{array}$ & $\begin{array}{l}2,29^{\mathrm{a}} \\
\pm 0,56\end{array}$ & $\begin{array}{l}35,61^{\mathrm{b}} \\
\pm 21,76 \\
\end{array}$ & $\begin{array}{r}6,58^{\mathrm{a}} \\
\pm 2,37 \\
\end{array}$ & $\begin{array}{r}6,45^{\mathrm{a}} \\
\pm 4,25 \\
\end{array}$ & $\begin{array}{l}4,63^{\mathrm{a}} \\
\pm 3,84\end{array}$ & $\begin{array}{r}3,74^{\mathrm{a}} \\
\pm 1,42 \\
\end{array}$ & $\begin{array}{l}11,48^{\mathrm{a}} \\
\pm 4,71 \\
\end{array}$ & 10,56 & $<0,001$ \\
\hline $\begin{array}{c}\text { Conductivity } \\
(\mu \mathrm{S} / \mathrm{cm})\end{array}$ & $\begin{array}{l}93,05^{\mathrm{a}} \\
\pm 4,07\end{array}$ & $\begin{array}{l}155,18^{b} \\
\pm 31,98\end{array}$ & $\begin{array}{l}88,08^{\mathrm{a}} \\
\pm 7,62\end{array}$ & $\begin{array}{r}83,22^{\mathrm{a}} \\
\pm 10,84 \\
\end{array}$ & $\begin{array}{l}67,83^{\mathrm{a}} \\
\pm 5,37 \\
\end{array}$ & $\begin{array}{l}69,07^{\mathrm{a}} \\
\pm 9,96 \\
\end{array}$ & $\begin{array}{r}78,53^{\mathrm{a}} \\
\pm 11,35 \\
\end{array}$ & 25,52 & $<0,001$ \\
\hline $\begin{array}{c}\text { Dissolved } \mathrm{O}_{2} \\
(\%)\end{array}$ & $\begin{array}{r}62,17^{\mathrm{a}} \\
\pm 12,41\end{array}$ & $\begin{array}{l}69,43^{\mathrm{ac}} \\
\pm 10,01\end{array}$ & $\begin{array}{l}92,75^{b} \\
\pm 8,26\end{array}$ & $\begin{array}{l}94,15^{\mathrm{b}} \\
\pm 8,68\end{array}$ & $\begin{array}{l}94,83^{b} \\
\pm 9,26\end{array}$ & $\begin{array}{l}95,03^{\mathrm{b}} \\
\pm 6,95\end{array}$ & $\begin{array}{l}84,32^{\mathrm{bc}} \\
\pm 10,42\end{array}$ & 6,96 & $<0,001$ \\
\hline
\end{tabular}


Table 3. Abundance of fishes collected in each stretch and in dry (D) and rainy (R) seasons in Córrego Rico, São Paulo State, Brazil. The four most abundant species are indicated with superscript numbers after the species name.

\begin{tabular}{|c|c|c|c|c|c|c|c|c|c|c|c|c|}
\hline \multirow{3}{*}{$\begin{array}{l}\text { Order } \\
\quad \text { Family } \\
\quad \text { Species }\end{array}$} & & \multirow{3}{*}{$\begin{array}{l}\text { Vouchers } \\
\text { (DZSJRP) }\end{array}$} & \multirow{2}{*}{\multicolumn{7}{|c|}{ Stretch }} & \multirow{2}{*}{\multicolumn{2}{|c|}{ Total }} & \multirow[b]{3}{*}{ Total } \\
\hline & & & & & & & & & & & & \\
\hline & & & S1 & S2 & S3 & S4 & S5 & S6 & S7 & D & $\mathrm{R}$ & \\
\hline \multicolumn{13}{|c|}{ CHARACIFORMES } \\
\hline \multicolumn{13}{|c|}{ Anostomidae } \\
\hline & $\begin{array}{l}\text { Leporthus Jrlaertcl } \\
\text { Lenorinus lacustris }\end{array}$ & 17668 & 0 & 0 & 0 & 0 & 0 & 0 & 2 & 1 & 1 & 2 \\
\hline & Leporinus obtusidens & $\begin{array}{l}17669 \\
17670\end{array}$ & 1 & 0 & 0 & 0 & 0 & 0 & 0 & 1 & 0 & 1 \\
\hline & Schizodon nasutus & $\begin{array}{l}17670 \\
17684\end{array}$ & 0 & 0 & $\begin{array}{l}0 \\
0\end{array}$ & $\begin{array}{l}0 \\
0\end{array}$ & $\begin{array}{l}0 \\
0\end{array}$ & $\begin{array}{l}1 \\
0\end{array}$ & 0 & $\begin{array}{l}1 \\
0\end{array}$ & 0 & $\begin{array}{l}1 \\
1\end{array}$ \\
\hline \multicolumn{13}{|l|}{ Characidae } \\
\hline & Aphyocharax dentatus & 17638 & 0 & 0 & 0 & 0 & 0 & 5 & 2 & 0 & 7 & 7 \\
\hline & Astyanax altiparanae & 17640 & 4 & 1 & 1 & 0 & 1 & 51 & 57 & 9 & 106 & 115 \\
\hline & Astyanax bockmanni & 17641 & 17 & 29 & 81 & 22 & 77 & 34 & 2 & 158 & 104 & 262 \\
\hline & Astyanax fasciatus $^{3}$ & 17642 & 171 & 147 & 122 & 52 & 27 & 38 & 48 & 203 & 402 & 605 \\
\hline & Astyanax schubarti & 17643 & 0 & 0 & 0 & 0 & 0 & 0 & 1 & 0 & 1 & 1 \\
\hline & Bryconamericus stramineus ${ }^{2}$ & 17644 & 50 & 64 & 343 & 333 & 25 & 74 & 48 & 261 & 676 & 937 \\
\hline & 'Cheirodon' stenodon ${ }^{4}$ & 17648 & 226 & 99 & 1 & 0 & 1 & 8 & 77 & 218 & 194 & 412 \\
\hline & Gymnocorymbus ternetzi & 17654 & 0 & 0 & 0 & 0 & 0 & 0 & 1 & 0 & 1 & 1 \\
\hline & Hemigrammus marginatus & 17656 & 0 & 0 & 0 & 0 & 0 & 4 & 6 & 0 & 10 & 10 \\
\hline & Hyphessobrycon anisitsi & 17660 & 3 & 0 & 0 & 0 & 0 & 0 & 0 & 0 & 3 & 3 \\
\hline & Hyphessobrycon eques & 17661 & 6 & 0 & 0 & 1 & 0 & 3 & 39 & 23 & 26 & 49 \\
\hline & Moenkhausia intermedia & 17671 & 0 & 0 & 0 & 0 & 0 & 3 & 0 & 0 & 3 & 3 \\
\hline & Odontostilbe sp. & 17672 & 0 & 0 & 0 & 0 & 0 & 15 & 0 & 15 & 0 & 15 \\
\hline & Oligosarcus pintoi & 17673 & 4 & 2 & 2 & 0 & 4 & 0 & 2 & 6 & 8 & 14 \\
\hline & Piabina argentea $^{1}$ & 17676 & 502 & 201 & 88 & 235 & 264 & 171 & 51 & 562 & 950 & 1512 \\
\hline & Salminus brasiliensis & 17683 & 0 & 0 & 0 & 0 & 0 & 0 & 3 & 0 & 3 & 3 \\
\hline & Serrapinnus heterodon & 17685 & 0 & 0 & 0 & 24 & 0 & 67 & 10 & 24 & 77 & 101 \\
\hline & Serrapinnus notomelas & 17686 & 127 & 25 & 2 & 0 & 3 & 17 & 32 & 46 & 160 & 206 \\
\hline \multirow[t]{3}{*}{ Crenuchidae } & Characidium gomesi & 17646 & 3 & 7 & 1 & 0 & 0 & 0 & 0 & 3 & 8 & 11 \\
\hline & Characidium sp. & 12211,12213 & 2 & 0 & 0 & 0 & 0 & 0 & 0 & 0 & 2 & 2 \\
\hline & Characidium zebra & 17647 & 48 & 3 & 7 & 1 & 1 & 1 & 2 & 43 & 20 & 63 \\
\hline \multicolumn{12}{|l|}{ Curimatidae } & 1 \\
\hline & Steindachnerina insculpta & 17687 & 60 & 6 & 35 & 0 & 3 & 2 & 11 & 71 & 46 & 117 \\
\hline \multicolumn{13}{|l|}{ Erythrinidae } \\
\hline & Hoplerythrinus unitaeniatus & 17658 & 0 & 0 & 0 & 0 & 0 & 0 & 1 & 0 & 1 & 1 \\
\hline & Hoplias malabaricus & 17659 & 8 & 4 & 1 & 0 & 1 & 0 & 1 & 8 & 7 & 15 \\
\hline \multicolumn{13}{|l|}{ Parodontidae } \\
\hline & Apareiodon sp. & $\begin{array}{c}12212,12214 \\
13617\end{array}$ & 0 & 0 & 0 & 0 & 0 & 0 & 4 & 0 & 4 & 4 \\
\hline & Apareiodon piracicabae & 17637 & 0 & 0 & 0 & 4 & 0 & 3 & 1 & 4 & 4 & 8 \\
\hline & Parodon nasus & 17675 & 0 & 0 & 0 & 2 & 0 & 0 & 1 & 0 & 3 & 3 \\
\hline 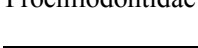 & Prochilodus lineatus & 17679 & 0 & 0 & 0 & 0 & 0 & 0 & 4 & 1 & 3 & 4 \\
\hline
\end{tabular}

abundant in stretches S3 andS4, and Serrapinnus notomelas $\left(\mathrm{r}=-0.57, \mathrm{r}^{2}=57.06 \%\right)$, abundant in stretch $\mathrm{S} 1$ (Table 3 ).

The environmental variables with highest correlations with NMDS axis 1 in the fish assemblage analysis were discharge $\left(\mathrm{r}=-0.63, \mathrm{r}^{2}=40.2 \%\right)$, width $\left(\mathrm{r}=-0.56, \mathrm{r}^{2}=31.3 \%\right)$ and nitrate $(\mathrm{r}=$ $\left.0.48, r^{2}=23.5 \%\right)$. For the second axis the variables were dissolved oxygen $\left(\mathrm{r}=0.73, \mathrm{r}^{2}=54.3 \%\right)$, ammonia $(\mathrm{r}=-0.61$, $\left.r^{2}=37.8 \%\right)$ and water velocity $\left(r=-0.58, r^{2}=33.6 \%\right)$.

\section{Discussion}

Environmental variables. Based on analysis of environmental variables, Córrego Rico can be divided into three groups that are distinguished primarily by concentrations of nutrients and dissolved oxygen. The first group, represented only by $\mathrm{S} 1$, is characterized by low levels of nutrients and dissolved oxygen. The second group, which includes stretches S2 and S7, which are just downstream treated sewage discharge, is characterized by high levels of nutrients (ammonia, nitrite and phosphorus). The third group, which includes stretches S3, S4, S5, and S6, is characterized by low nutrient levels and high dissolved oxygen concentrations. Less water turbulence and high levels of biological activity alters the levels of oxygen in water (Allan, 1995). Therefore, the lentic characteristic of the small lake upstream stretch S1, with low flow velocity and large amount of unconsolidated substrate, reduces the level of oxygen in stretches S1 and S2. Excessive concentrations of phosphorus and nitrogen, as observed in stretches S2 and S7, can lead to eutrophication, which can affect the fauna due to microbial metabolism that reduces dissolved oxygen (Khan \& Ansari, 2005). However stretches S1 and S2 had low dissolved oxygen concentrations, but differed in dissolved nutrient concentration. Again, low oxygen concentration in S2 is due to the influence of the small lake, rather than, nutrient loading from the local 
Table 3. cont. Abundance of fishes collected in each stretch and in dry (D) and rainy (R) seasons in Córrego Rico, São Paulo State, Brazil. The four most abundant species are indicated with superscript numbers after the species name.

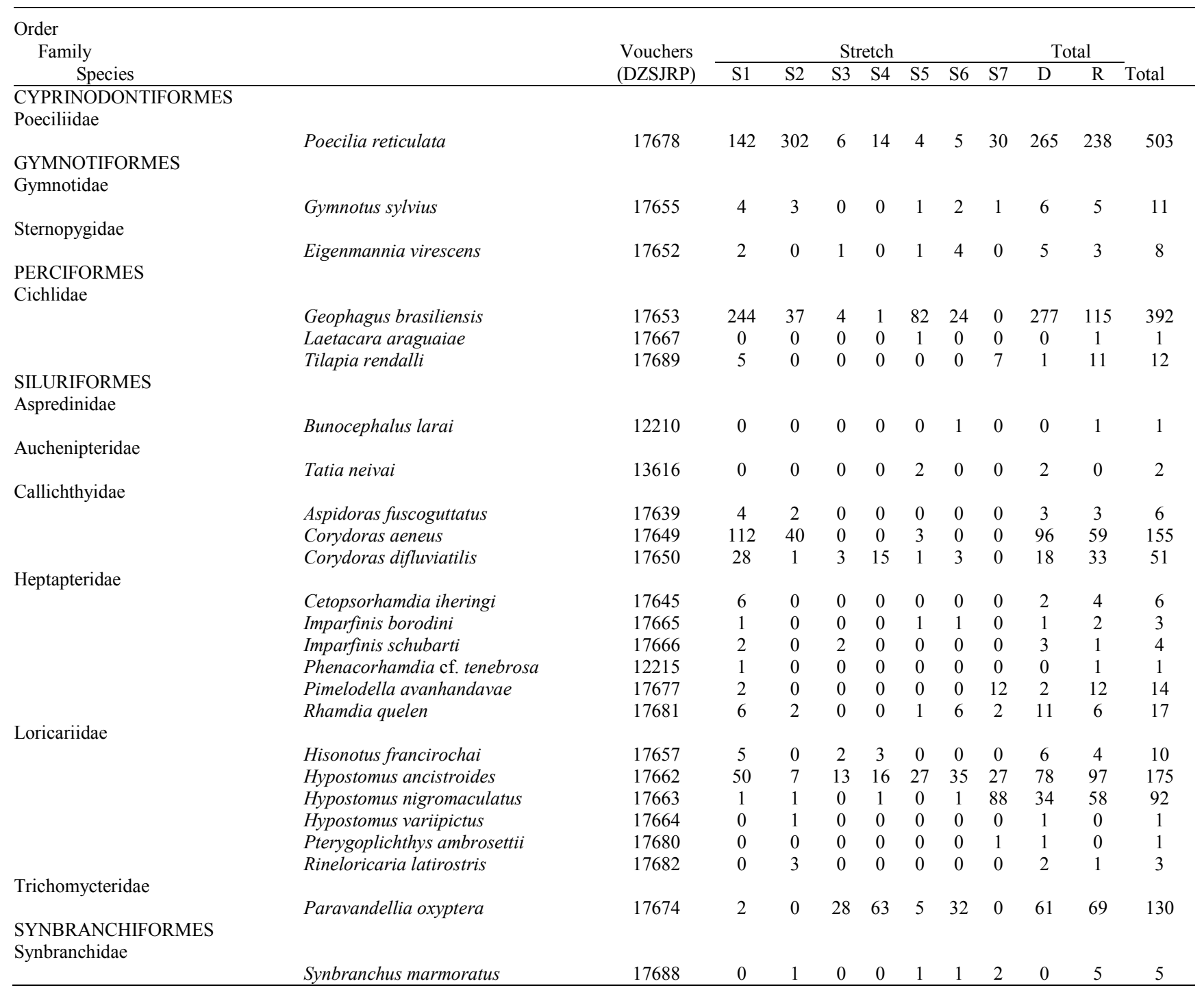

watershed. The presence of riffles, with fast and turbulent waters in stretches S3, S4 and S5 and the great distance from treated sewage discharge likely account for the high levels of dissolve oxygen and the low nutrient concentrations in these stretches.

Spatial pattern of fish assemblage. Analysis of fish assemblage composition in Córrego Rico stream also identified three main groups: one composed of the two upper stretches S1 and S2, the other by the middle stretches S3, S4 and S5, and a last one by stretches $\mathrm{S} 6$ and $\mathrm{S} 7$. These groups were strongly influenced by species that are abundant in the Mogi Guaçu River, its tributaries and oxbow lakes (Meschiatti \& Arcifa, 2009). For example, Serrapinnus heterodon was common in middle and lower stretches of Córrego Rico stream. Piabina argentea and Geophagus brasiliensis were abundant in upper stretches. 'Cheirodon' stenodon and S. notomelas were abundant only in the upper and lower stretches. Paravandellia oxyptera was abundant only in the middle stretches.

Instream and riparian habitat variables significantly influenced fish assemblage structure in Córrego Rico, and these undoubtedly have been influenced by urbanization and sugar cane farming in the watershed. Abes et al. (2001) documented higher species richness in streams of the upper Paraná River basin that had more intact riparian vegetation. In Córrego Rico, the environmental variables having strongest correlations with fish assemblage structure were channel structural features, dissolved oxygen, and nutrients. Despite certain environmental differences between $\mathrm{S} 1$ and S2, their fish assemblage structures were quite similar. These stretches had different dissolved nutrients, but their width, depth, discharge and dissolved oxygen were similar. Low dissolved oxygen in $\mathrm{S} 1$ and $\mathrm{S} 2$ did not inhibit the population of Corydoras aeneus, a species possessing accessory 

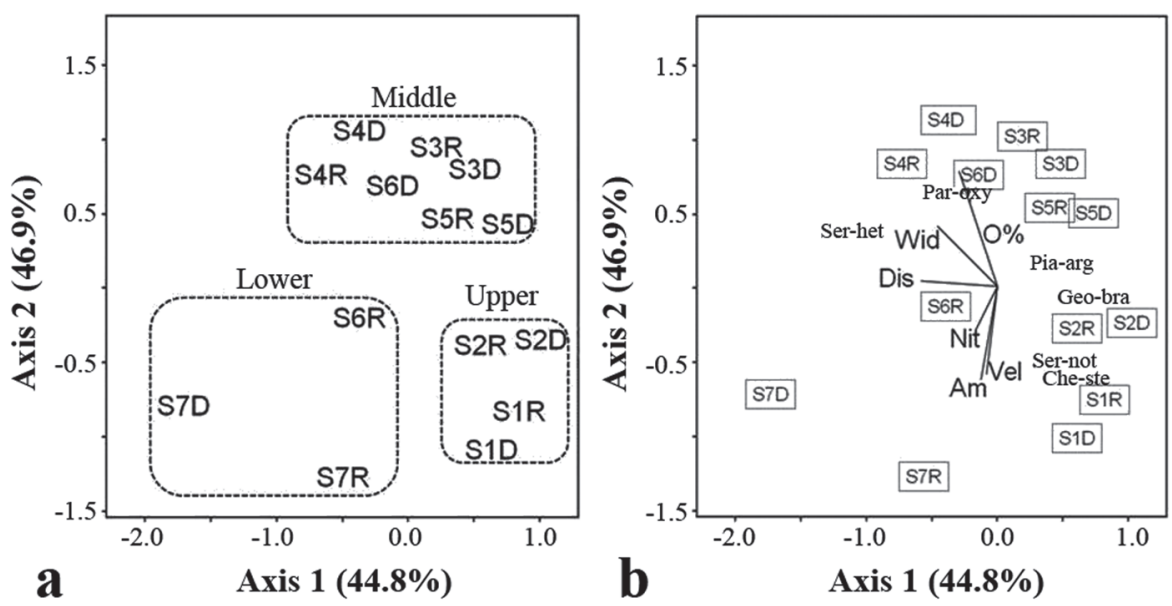

Fig. 3. Non-metric multidimensional scaling (NMDS) ordination based on fish abundance data from Córrego Rico: a) Stretches grouped in upper, middle and lower (S1 to S7; d- dry season and r- rainy season). b) Stretches (S1 to S7; d- dry season and r- rainy season); fish species with highest correlations with the axis (Ser-het: Serrapinnus heterodon; Par-oxy: Paravandellia oxyptera; Pia-arg: Piabina argentea; Geo-bra: Geophagus brasiliensis; Ser-not: Serrapinnus notomelas; Che-est: 'Cheirodon' stenodon); environmental variables with highest correlations with the fish assemblage (Dis: discharge; Wid: width; O\%: dissolved oxygen; Vel: water velocity; Am: ammonia; Nit: Nitrate). Vectors show the direction and magnitude of correlations.

respiratory adaptations (Kramer \& Mcclure, 1980), which is common in middle and lower stretches of streams in this region (Aranha et al., 1993; Casatti, 2005). 'Cheirodon' stenodon and $A$. fasciatus were also abundant in upper stretches of Córrego Rico. The small lake above S1 supports large populations of these species and may serve as a source for many individuals encountered in the stream within the upper stretches. For other fish species, nutrient loading from the cities and agricultural fields in the upper stream reaches appeared to have negative effects. Characidium zebra occurs mainly within low-order streams in areas with relatively high water velocity (Casatti \& Castro, 1998). In Córrego Rico, $C$. zebra was abundant only in riffle areas within S1. High abundance of Poecilia reticulata, an exotic species, in stretch S2 supports the idea that nutrient inputs have a significant impact on stream fishes (Casatti et al., 2006a; Cunico et al., 2006).

The middle stretches ( $\mathrm{S} 3, \mathrm{~S} 4$, and $\mathrm{S} 5$ ) had high values for dissolved oxygen, low values for nutrients, and high abundance of only one species, Bryconamericus stramineus. This species inhabits the water column and seems to be associated with habitats lacking physical disturbance to the channel (Casatti et al., 1998; Casatti et al., 2002; Casatti et al., 2006b). The bedrock substrate, dominance of running-water

Table 4. Summary of ecological parameters in dry (d) and rainy (r) seasons by survey stretches (S1 to S7). Student's $t$-test of H' differences between survey stretches. Sample size in rarefaction method is 118 individuals.

\begin{tabular}{|c|c|c|c|c|c|c|c|c|c|c|c|c|c|c|}
\hline S1d & S2d & S3d & S4d & S5d & S6d & S7d & S1r & S2r & S3r & S4r & S5r & S6r & S7r & Stretches \\
\hline 15,55 & 12,02 & 13,25 & 11,09 & 12,38 & 16,31 & 16,95 & 16,34 & 13,82 & 8,82 & 9,76 & 12,34 & 17,48 & 19,88 & \multirow{2}{*}{$\begin{array}{c}\text { Richness } \\
\text { standard } \\
\text { deviation }\end{array}$} \\
\hline 1,74 & 1,52 & 1,54 & 1,05 & 1,71 & 1,31 & 0,22 & 1,81 & 1,55 & 1,39 & 1,02 & 1,43 & 1,60 & 1,91 & \\
\hline \multirow[t]{14}{*}{2,30} & 1,78 & 1,96 & 1,83 & 1,74 & 2,11 & 2,25 & 2,26 & 2,17 & 1,43 & 1,44 & 1,54 & 2,46 & 2,64 & Shannon Index \\
\hline & $<0,05$ & $<0,05$ & $<0,05$ & $<0,05$ & $<0,05$ & 0,16 & 0,35 & 0,01 & $<0,05$ & $<0,05$ & $<0,05$ & $<0,05$ & $<0,05$ & S1d \\
\hline & & $<0,05$ & 0,59 & 0,53 & $<0,05$ & $<0,05$ & $<0,05$ & $<0,05$ & $<0,05$ & $<0,05$ & $<0,05$ & $<0,05$ & $<0,05$ & S2d \\
\hline & & & 0,14 & $<0,05$ & 0,21 & $<0,05$ & $<0,05$ & $<0,05$ & $<0,05$ & $<0,05$ & $<0,05$ & $<0,05$ & $<0,05$ & S3d \\
\hline & & & & 0,28 & $<0,05$ & $<0,05$ & $<0,05$ & $<0,05$ & $<0,05$ & $<0,05$ & $<0,05$ & $<0,05$ & $<0,05$ & S4d \\
\hline & & & & & $<0,05$ & $<0,05$ & $<0,05$ & $<0,05$ & $<0,05$ & $<0,05$ & 0,06 & $<0,05$ & $<0,05$ & S5d \\
\hline & & & & & & 0,45 & 0,05 & 0,36 & $<0,05$ & $<0,05$ & $<0,05$ & $<0,05$ & $<0,05$ & S6d \\
\hline & & & & & & & 0,35 & 0,95 & $<0,05$ & $<0,05$ & $<0,05$ & $<0,05$ & $<0,05$ & S7d \\
\hline & & & & & & & & 0,10 & $<0,05$ & $<0,05$ & $<0,05$ & $<0,05$ & $<0,05$ & S1r \\
\hline & & & & & & & & & $<0,05$ & $<0,05$ & $<0,05$ & $<0,05$ & $<0,05$ & S2r \\
\hline & & & & & & & & & & 0,85 & 0,36 & $<0,05$ & $<0,05$ & S3r \\
\hline & & & & & & & & & & & 0,43 & $<0,05$ & $<0,05$ & S4r \\
\hline & & & & & & & & & & & & $<0,05$ & $<0,05$ & S5r \\
\hline & & & & & & & & & & & & & $<0,05$ & S6r \\
\hline
\end{tabular}


habitat, relatively high levels of dissolved oxygen and low levels of nutrients in segments of the middle reach (S3, S4) were associated with high abundance of $B$. stramineus. However, the favorable physical habitat of the middle stretches did not agree with the observed low values of species richness obtained by the rarefaction method and diversity, suggesting negative influence of the dam.

Upper stretches, S6 and S7 were not grouped between them and with others stretches, but they have in common high values of species richness and diversity. The proximity with Mogi Guaçu River contributes to this pattern, and thus some species were collected only in these stretches. Astyanax altiparanae, a specie very common and widely distributed in Paraná River basin streams (Britski, 1972), was collected only in these stretches, mainly in rainy season. Ferreira \& Casatti (2006) explain the high abundance of the armored catfish $H$. nigromaculatus in lower stretch of a stream from upper Paraná river due to the rocky substrate predominance. A similar pattern was observed in the Córrego Rico. Hypostomus nigromaculatus was abundant only in stretch S7 where there was large amount of bedrock. Juveniles of Salminus brasiliensis and Prochilodus lineatus, which are mediumlarge body size migratory fishes (Agostinho et al., 2003), were collected only in stretch S7.

High values of species richness and diversity were obtained for the upper and lower stretches, and middle stretches had low values of species richness and diversity. Given these patterns of species distribution, it appears that Córrego Rico does not conform to the predictions of the river continuum concept (Vannote et al., 1980). According to this theory there is an increase in species richness from upstream to downstream because of greater habitat size and complexity. Increase in species richness among stretches towards the river mouth has been documented for some rivers in Paraná basin (Abes et al., 2001; Ferreira \& Casatti, 2006). However, the river continuum concept may not apply for fluvial systems that have distinct geological and geomorphic zones or that have undergone anthropogenic modifications (Naiman et al., 1988). It is suggested that connectivity can explain high species richness and diversity in upper and lower stretches. The small lake above stretch S1 has a habitat structure very similar with a large pool habitat. In general, these habitats show high species richness due to the combination of the substrate, water velocity, depth and width of the channel (Langeani et al., 2005; da Silva et al., 2007; Abilhoa et al., 2008). Therefore, high species richness and diversity in upper and lower stretches are due to the permanent connectivity with the small lake and Mogi Guacu River, respectively. Connectivity is documented as a strong predictor to fish assemblages (Isaak et al., 2007; Thomaz et al., 2007; Sullivan $\&$ Watzin, 2009). Moreover, Córrego Rico has been impacted by human actions in several stretches. The low dam in the middle stretches (between S3 and S4) clearly has a strong negative influence on fish assemblage. It is well documented that large dams negatively influence the freshwater fish fauna (Agostinho et al., 2002; Barrella \& Petrere, 2003). As fish fauna from Córrego Rico is characterized mainly by small size species, even a small dam can modify the fish assemblage. For small dams Benstead et al. (1999), Tiemman et al. (2004), and Gillete et al. (2005) demonstrated that they can indeed affect the fauna assemblage in temperate regions and in Porto Rico, Central America. In Córrego Rico, the spatial distribution of $S$. heterodon seems to be evidence of the negative influence of the small dam. This small size specie was documented in three Mogi Guacu River's tributaries in middle and lower stretches (Oliveira \& Garavello, 2003; Perez-Junior \& Garavello, 2007; Apone et al., 2008). In Córrego Rico, Serrapinnus heterodon was collected only in medium and lower stretches (S4, S6, and S7), but almost all species collected in $\mathrm{S} 4$ were collected in $\mathrm{S} 3$ or upper stretches, and $\mathrm{S} 3$ and $\mathrm{S} 4$ are very close. Therefore, the dam fragmented Córrego Rico and limited $S$. heterodon to middle and lower stretches. Habitat fragmentation due to dams were documented by Burns et al. (2006) and Gosset et al.(2006).

Seasonal pattern. Seasonal differences were not evident on fish assemblage composition in upper and middle stretches. However, some stretches showed differences in species richness and diversity. Stretches S3 and S4 showed higher values of these indices in the dry season. According with Súarez et al. (2006), water velocity is a limiting factor for some species. Thus, the increase in flow, due to the rainy season, increases the water velocity in riffles, which is the predominant factor in stretches S3 and S4 explaining the low values of species richness and diversity in rainy season. Another factor that should be considered to explain this pattern is the fragmentation caused by the dam, as discussed earlier.

Seasonal differences in fish assemblage structure in Córrego Rico were observed only in the two lower stretches (S6, S7), a pattern that probably was influenced by connectivity and seasonal migration from the Mogi Guaçu River. In Neotropical areas, during the rainy season, there is more water in the rivers and streams that creates more habitats. Also, most fish species reproduce during the rainy season (LoweMcConnell, 1987). Fishes from Mogi Guaçu River ascend Córrego Rico during the rainy season, and greater abundance was observed in the two lower stretches (S6, S7) during that time. The species assemblage structure of S6 was similar to stretches S3, S4 and S5 during the dry season, but during the rainy season S6 was most similar to S7. This finding further supports the idea that S6 and S7 are strongly influenced by their connectivity to the Mogi Guaçu River. Seasonal differences in lower stretches also could have been influenced by connectivity with more extensive floodplain habitats (Valerio et al., 2007).

The lack of seasonal differences in upper and middle stretches of Córrego Rico may be due to their narrower floodplains as well as their conversion into sugar cane fields. Negative impacts in aquatic environment due to sugar cane cultivate in Neotropical areas were reported by Martinelli et al., (2008) and Gunkel et al., (2007). In Córrego Rico basin, siltation, erosion and soil management reduced riparian 
vegetation and flooded areas. According to Lowe-McConnell (1987), the flood pulse is the most important factor influencing seasonal ecological dynamics in Neotropical rivers. Thomas et al. (2007), reinforce the importance of flood and connectivity to the increase in similarity in aquatic habitats. Therefore, the reduction of flooded areas during the rainy season limits the occupation of fish species, explaining the lack of seasonal variation. Little seasonal variation in fish assemblage composition has been observed in other upland streams of the upper Paraná River basin (Ferreira \& Casatti, 2006; Valerio et al., 2007; Y. R. Súarez et al., 2007).

In summary, the fish assemblages of the Córrego Rico were grouped into upper, middle and lower stretches, with highest species richness and diversity in the upper and lower stretches. Fish assemblage in upper stretches were influenced by connectivity with a small lake, middle stretches by a small dam and lower stretches by the connectivity with Mogi Guaçu River. The combination of water velocity, depth and width of the channel, dissolved oxygen and nutrient concentrations had the strongest correlations with the fish assemblage structure. Seasonal difference in species assemblage structure was observed only in the lower stretches, and this appears to be strongly influenced by seasonal migrations of fishes from the nearby Mogi Guaçu River.

\section{Acknowledgments}

We thanks to Marcelo Assunção, Nivaldo Nascimento and students from UNESP Jabotical for help in the samples. We thank Kirk Winemiller for suggestions, and English improvement. We thank Conselho Nacional de Desenvolvimento Científico e Tecnológico (CNPq) for funding. We thank reviewers for helpful and valuable suggestions.

\section{Literature Cited}

Abes, S. D. \& A. A. Agostinho. 2001. Spatial patterns in fish distributions and structure of the ichthyocenosis in the Agua Nanci stream, upper Parana River basin, Brazil. Hydrobiologia, 445: 217-227.

Abilhoa, V., L. F. Duboc \& D. P. de Azevedo. 2008. The fish community in an Araucaria Forest stream, upper Iguaçu River basin, southern Brazil. Revista Brasileira de Zoologia, 25: 238-246.

Agostinho, A. A., L. C. Gomes, D. R. Fernandez \& H. I. Suzuki. 2002. Efficiency of fish ladders for neotropical ichthyofauna. River Research and Applications, 18: 299-306.

Agostinho, A. A., L. C. Gomes, H. I. Suzuki \& H. F. Julio, 2003. Migratory fish from the upper Paraná River basin, Brazil. Pp.19-99. In: Carolsfeld, J., B. Harvey, C. Ross, A. Baer \& C. Ross (Eds.). Migratory Fishes of South America: Biology, Social Importance and Conservation Status. Victoria,World Fisheries Trust, Britsh Columbia, 380p.

Agostinho, A. A., F. M. Pelicice, A. C. Petry, L. C. Gomes \& H. E. Julio. 2007. Fish diversity in the upper Paraná River basin: habitats, fisheries, management and conservation. Aquatic Ecosystem Health \& Management, 10: 174-186.

Allan, J. D. 2007. Stream ecology: structure and function of running waters. Dordrecht, Springer, 388p.
Angermeier, P. L. \& I. J. Schlosser. 1989. Species-Area Relationships for Stream Fishes. Ecology, 70: 1450-1462.

Apone, F., A. K. Oliveira \& J. C. Garavello. 2008. Composição da ictiofauna do rio Quilombo, tributário do rio Mogi-Guaçu, bacia do alto rio Paraná, sudeste do Brasil. Biota Neotropica, 8: 93-107.

Aranha, J. M. R., E. P. Caramaschi \& U. Caramaschi. 1993. Ocupação espacial, alimentação e época reprodutiva de duas espécies de Corydoras Lacépède (Siluroidei, Callichthyidae) coexistentes no rio Alambari (Botucatu, São Paulo). Revista Brasileira de Zoologia, 10: 453-466.

Barrella, W. \& M. Petrere. 2003. Fish community alterations due to pollution and damming in Tietê and Paranapanema rivers (Brazil). River Research and Applications, 19: 59-76.

Benstead, J. P., J. G. March, C. M. Pringle \& F. N. Scatena. 1999. Effects of a low-head dam and water abstraction on migratory tropical stream biota. Ecological Applications, 9: 656-668.

Borges, M. J., J. A. Galbiati \& A. S. Ferraudo. 2003. Monitoramento da qualidade hídrica e eficiência de interceptores de esgoto em cursos d'água urbanos na bacia hidrográfica do córrego Jaboticabal. Revista Brasileira de Recursos Hídricos, 8: 161-171.

Britski, H. A. 1972. Peixes de água doce do Estado de São Paulo. Pp.73-78. In: Branco, S. M. (Org.). Poluição e Piscicultura. São Paulo, Faculdade de Saúde Pública da USP and Instituto de Pesca, 216p.

Burns, M. D. M., A. M. Garcia, J. P. Vieira, M. A. Bemvenuti, D. M. L. M. Marques \& V. Condini. 2006. Evidence of habitat fragmentation affecting fish movement between the Patos and Mirim coastal lagoons in southern Brazil. Neotropical Ichthyology, 4: 69-72.

Casatti, L. 2005. Fish assemblage structure in a first order stream, southeastern Brazil: longitudinal distribution, seasonality, and microhabitat diversity. Biota Neotropica, 5: 75-83.

Casatti, L. \& R. M. C. Castro. 1998. A fish community of the São Francisco River headwaters riffles, southeastern Brazil. Ichthyological Exploration of Freshwaters, 9: 229-242.

Casatti, L., F. Langeani \& R. M. C. Castro. 2002. Peixes de riacho do Parque Estadual Morro do Diabo, bacia do alto rio Paraná, SP. Biota Neotropica, 2: 1-14.

Casatti, L., F. Langeani \& C. P. Ferreira. 2006a. Effects of physical habitat degradation on the stream fish assemblage structure in a pasture region. Environmental Management, 38: 974-982.

Casatti, L., F. Langeani, A. M. Silva \& R. M. C. Castro. 2006b. Stream fish, water and habitat quality in a pasture dominated basin, southeastern Brazil. Brazilian Journal of Biology, 66: 681-696.

Cunico, A. M., A. A. Agostinho \& J. D. Latini. 2006. Influence of urbanization upon fish assemblages in three streams of Maringa, Paraná. Revista Brasileira de Zoologia, 23: 1101-1110.

da Silva, E. F., C. E. de Melo \& P. C. Venere. 2007. Factors influencing the fish community in two environments in the lower Rio das Mortes, Bananal floodplain, Mato Grosso, Brazil. Revista Brasileira de Zoologia, 24: 482-492.

Eaton A.D., L. S. Clesceri \& A. E. Greenberg, (Eds.). 1995. Standard Methods for the Examination of Water and Wastewater, $19^{\text {th }}$ Ed. Whashington, American Public Health Association, 2670p.

Ferreira, C. D. P. \& L. Casatti. 2006. Habitat structure and stream fishes in a pasture basin, São Paulo, Brazil. Revista Brasileira de Zoologia, 23: 642-651.

Gillette, D. P., J. S. Tiemann, D. R. Edds \& M. L. Wildhaber. 2005. Spatiotemporal patterns of fish assemblage structure in a river impounded by low-head dams. Copeia, 2005: 539-549. 
Gosset, C., J. Rives \& J. Labonne. 2006. Effect of habitat fragmentation on spawning migration of brown trout (Salmo trutta L.). Ecology of Freshwater Fish, 15: 247-254.

Gunkel, G., J. Kosmol, M. Sobral, H. Rohn, S. Montenegro \& J. Aureliano. 2007. Sugar Cane Industry as a Source of Water Pollution - Case Study on the Situation in Ipojuca River, Pernambuco, Brazil. Water Air Soil Pollution, 180: 261-269.

Hammer, O., D. A. T. Harper \& P. D. Ryan, 2001. PAST: Paleontological Statistics software package for education and data analysis. In: Electronica, P. (Ed.). Oslo.

Horton, R. E. 1945. Erosional development of streams and theirdrainage basins: hidrophysical approach to quantitative morphology. Bulletin of Geological Society of America, 56: 275-370, 1945 .

Isaak, D. J., R. F. Thurow, B. E. Rieman \& J. B. Dunham. 2007. Chinook salomons use of spawning patches: relative roles of habitat quality, size and connectitity. Ecological Applications, 17: 352-364.

Khan, F. A. \& A. A. Ansari. 2005. Eutrophication: An ecological vision. Botanical Review, 71: 449-482.

Kramer, D. L. \& M. Mcclure. 1980. Aerial Respiration in the Catfish, Corydoras aeneus (Callichthyidae). Canadian Journal of Zoology, 58: 1984-1991.

Langeani, F., L. Casatti, H. S. Gameiro, A. B. Carmo \& D. C. RossaFeres. 2005. Riffle and pool fish communities in a large stream of southeastern Brazil. Neotropical Ichthyology, 3: 305-3011.

Lowe-McConnell, R. 1987. Ecological studies in tropical fish communities. Cambridge, Cambridge University Press, 382p.

Magurran, A. E. 1988. Ecological diversity and its measurement. Princeton, Princeton University Press, 179p.

Martinelli, L. A. \& S. Filoso. 2008. Expansion of sugarcane ethanol production in Brazil: environmental and social challenges. Ecological Applications, 18: 885-898.

McCune, B. \& M. J. Mefford, 2006. PC-ORD. Multivariate Analysis of Ecological Data. MjM Software Design, Gleneden Beach.

Meschiatti, A. J. \& M. S. Arcifa. 2009. A review on the fishfauna of Mogi-Guaçu River basin: a century of studies. Acta Limnologica Brasiliensia, 21: 135-159.

Naiman, R. J., H. Décamps, J. Pastor \& C. A. Johnston. 1988. The potential importance of boundaries to fluvial ecosystems. Journal of the North American Benthological Society, 7: 289-306.

Oliveira, A. K. \& J. C. Garavello. 2003. Fish assemblage composition in a tributary of the Mogi Guaçu river basin, southeastern Brazil. Iheringia. Série Zoologia, 93: 127-138.

Penczak, T., A. A. Agostinho \& E. K. Okada. 1994. Fish diversity and community structure in two small tributaries of the Paraná River, Parana State, Brazil. Hydrobiologia, 294: 243-251.

Perez-Junior, O. R. \& J. C. Garavello. 2007. Ictiofauna do Ribeirão do Pântano, afluente do Rio Mogi-Guaçu, Bacia do Alto Rio Paraná, São Paulo, Brasil. Iheringia. Série Zoologia, 97: 328-335.

Poff, N. L. \& J. D. Allan. 1995. Functional-organization of stream fish assemblages in relation to hydrological variability. Ecology, 76: 606-627.

Pringle, C. M., M. C. Freeman \& B. J. Freeman. 2000. Regional effects of hydrologic alterations on riverine macrobiota in the New World: Tropical-temperate comparisons. Bioscience, 50: 807-823.

Ribeiro, A. C. 2006. Tectonic history and the biogeography of the freshwater fishes from the coastal drainages of eastern Brazil: an example of faunal evolution associated with a divergent continental margin. Neotropical Ichthyology, 4: 225-246.

Sousa, R., M. Rufino, M. Gaspar, C. Antunes \& L. Guilhermino. 2008. Abiotic impacts on spatial and temporal distribution of Corbicula fluminea (Muller, 1774) in the River Minho Estuary, Portugal. Aquatic Conservation: Marine and Freshwater Ecosystems, 18: 98-110.

Strahler, A. N. 1957. Quantitative analysis of watershed geomorphology. Transactions of the American Geophysical Union, 38: 913-920.

Súarez, Y. R. \& M. Petrere. 2006. Diversity gradients in fish communities of Iguatemi river basin, Mato Grosso do Sul, Brazil. Iheringia Serie Zoologia, 96: 197-204.

Súarez, Y. R., S. B. Valério, K. K. Tondato, L. Q. L. Ximenes \& T. R. A. Felipe. 2007. Determinantes ambientais da ocorrência de espécies de peixes em riachos de cabeceira da bacia do rio Ivinhema, alto rio Paraná. Acta Scientiarum Biological Sciences, 29: 145-150.

Sullivan, S. M. P. \& M. C. Watzin. 2009. Stream-floodplain connectivity and fish assemblage diversity in the Champlain Valley, Vermont, U.S.A. Journal of Fish Biology, 74: 1394-1418.

Taylor, C. M. 1997. Fish species richness and incidence patterns in isolated and connected stream pools: Effects of pool volume and spatial position. Oecologia, 110: 560-566.

Taylor, C. M. \& M. L. Warren. 2001. Dynamics in species composition of stream fish assemblages: Environmental variability and nested subsets. Ecology, 82: 2320-2330.

Taylor, C. M., T. L. Holder, R. A. Fiorillo, L. R. Williams, R. B. Thomas \& M. L. Warren. 2006. Distribution, abundance, and diversity of stream fishes under variable environmental conditions. Canadian Journal of Fisheries and Aquatic Sciences, 63: 43-54.

Thomaz, S. M., L. M. Bini \& R. L. Bozelli. 2007. Floods increase similarity among aquatic habitats in river-floodplain systems. Hidrobiologia, 579: 1-13.

Tiemann, J. S., D. P. Gillette, M. L. Wildhaber \& D. R. Edds. 2004. Effects of lowhead dams on riffle-dwelling fishes and macroinvertebrates in a midwestern river. Transactions of the American Fisheries Society, 133: 705-717.

USEPA, 1997. Volunteer stream monitoring: a methods manual. Washington, 227p.

Valerio, S. B., Y. R. Suarez, T. R. A. Felipe, K. K. Tondato \& L. Q. L. Ximenes. 2007. Organization patterns of headwater-stream fish communities in the Upper Paraguay-Parana basins. Hydrobiologia, 583: 241-250.

Vannote, R. L., G. W. Minshall, K. W. Cummins, J. R. Sedell \& C. E. Cushing. 1980. River Continuum Concept. Canadian Journal of Fisheries and Aquatic Sciences, 37: 130-137.

Walters, D. M., D. S. Leigh, M. C. Freeman, B. J. Freeman \& C. M. Pringle. 2003. Geomorphology and fish assemblages in a Piedmont river basin, USA. Freshwater Biology, 48: 1950-1970.

Winemiller, K. O., S. Tarim, D. Shormann \& J. B. Cotner. 2000. Fish assemblage structure in relation to environmental variation among Brazos River oxbow lakes. Transactions of the American Fisheries Society, 129: 451-468.

Submitted September 20, 2011

Accepted September 21, 2012 by Alexandre Miranda Garcia Published March 31, 2013 